\title{
3D VIRTUAL MODELLING OF EXISTING OBJECTS BY TERRESTRIAL PHOTOGRAMMETRIC METHODS - CASE STUDY OF BARUTANA
}

\author{
Petar Pejić, Sonja Krasić, Hristina Krstić, Magdalena Dragović, Yağız Akbiyik
}

Professional paper

Three dimensional virtual modelling of existing objects (buildings or structures) is applicable in various fields of science and practice: architecture, civil engineering, urbanism, geology, mechanical engineering, video games and movie industry, medicine, archeology, safety of people and goods, etc. Photogrammetry, as a method of obtaining data of three-dimensional spatial structures based on two-dimensional images, is used, thanks to a number of software packages, for creating 3D models of objects and other spatial structures. This study analyses terrestrial semiautomatic and automatic photogrammetric methods, both presented through process of creating 3D model of an old existing historical building - Barutana (military gun powder warehouse), built in Ottoman empire, located in the fortress of the city of Niš in Serbia. The aim of the paper is comparison of two photogrammetric methods - semiautomatic and automatic in accuracy and efficiency through case study of Barutana.

Keywords: automatic photogrammetry; Barutana; existing objects; semiautomatic photogrammetry; virtual 3D models.

Kreiranje virtualnih 3D modela izgrađenih objekata metodama zemaljske fotogrametrije - studija slučaja Barutana

Stručni članak

Kreiranje trodimenzijskih virtualnih modela postojećih objekata primjenjuje se u različitim područjima znanosti i prakse. Ovakvi 3D modeli se koriste u arhitekturi, građevinarstvu, urbanizmu, geologiji, strojarstvu, industriji video igara, filmskoj industriji, medicini, arheologiji, za sigurnost ljudi i dobara itd. Fotogrametrija kao metoda dobivanja podataka trodimenzijske prostorne strukture na osnovu dvodimenzijskih fotografija, zahvaljujući mnogobrojnim softverskim paketima koristi se za izradu 3D modela objekata i prostornih struktura. U ovom radu su analizirane zemaljska poluautomatska i automatska metoda fotogrametrije. Obje pomenute metode su u radu predstavljene kroz studiju slučaja izrade 3D modela Barutane iz doba otomanske imperije, koja se nalazi u Niškoj tvrđavi u Srbiji. Cilj rada je da se kroz studiju slučaja izrade virtualnog 3D modela Barutane provede analiza poluautomatske i automatske metode fotogrametrije i usporedi njihova preciznost.

Ključne riječi: automatska fotogrametrija; Barutana; polu automatska fotogrametrija; postojeći objekti; virtualni $3 D$ modeli

\section{Introduction}

Computer modelling of existing objects (buildings or structures) provided by numerous software solutions has its wide pallet of application in science and practice: architecture $[1 \div 8]$, civil engineering $[9 \div 15]$, urbanism $[16 \div 19]$, geology $[20 \div 24]$, mechanical engineering $[25]$ (Menna and Nocerino 2012), video games and movie

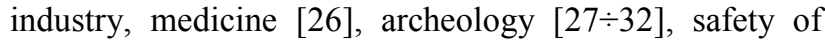
people and goods [33], etc.

Three-dimensional models of existing buildings and urban structures are used for the purpose of visual presentation, documentation and archiving their physical structure or for the implementation of various analyses. In the architecture, models are equally useful for design processes and modelling of existing buildings, presentations of surroundings employed in new projects, as well as urban structure of some location. Models are of importance in cultural heritage documentations, reconstructions, or restorations of buildings damaged during time or the inaccessible ones. Contemporary analyses concerning: insulation, shadow spreading, acoustic, thermal imaging, etc. [34] can be more efficiently carried out with 3D models of existing urban structures, or buildings.

Each one of the mentioned applications of 3D models of existing buildings involves various levels of details and realistic presentations of virtual model's textures. Regarding variety of objects, locations, or desired level of details, different methods and methodologies in documentation design process are available. The choice of adequate method depends on the following parameters: - aim of research,
- demanded geometrical precision and visual quality, - physical characteristics of building and its surroundings and

- $\quad$ expendable budget.

Three dimensional models of buildings, originated from simple methods of manual data collecting (measurements) and drawings, had been developed to advanced technologies offering automatic generating of 3D elements, or entire objects, as well as urban entities [35]. Virtualization based on manually collected geometrical dimensions takes a lot of time and it is outdated because of high costs when big projects are concerned. These 3D models have no colour and realistic textures, i.e. there is lack of details [35]. In comparison to traditional models, contemporary digital methods of laser scanning $[24,27,36 \div 40]$ and photogrammetry $[2,6,19$, $27,37,41 \div 47$ ] provide very accurate presentations of object's characteristics containing the following analyses: surface, structure (construction), behaviour in certain conditions, as well as realistic visual presentation.

Photogrammetric method gives information about 3D structure, obtained from 2D photographs [48]. Photogrammetry is a technique of representing and measuring 3D objects using data stored on 2D photographs, which are the base for rectification. At least two projections are necessary to obtain information about three space coordinates, that is, from two photographs of the same objects its true size can be determined and 3D model constructed [49].

According to the position (point of view) of a "photographer", photogrammetry is named terrestrial, or areal. Terrestrial photogrammetry is the best choice (method) in terms of: data collecting, availability of 
adequate software packages and entire process costs [34]. This case study presents generating process of $3 \mathrm{D}$ model of old Barutana, located in Ottoman fortress of the city of Niš, obtained by two terrestrial photogrammetric methods: semiautomatic and automatic. Virtualization process of this building by semiautomatic method is aided with "Tgi3D Photo Scan" and "Sketch Up" software packages, while the automatic photogrammetric method for 3D model of Barutana employed "123D Catch". Conducted analyses had the intention of precise determination of advantages, i.e. disadvantages for both methods and comparison of their accuracy.

\section{The materials and methods}

Barutana, military building for gun powder and munitions storing, object of this analysis, is located in Ottoman fortress of the city of Niš, on the Balkan Peninsula in the Republic of Serbia (Fig. 1). There are five preserved buildings (powder warehouses) in the fortress: four of them are located along the north bastion and a smaller one in the eastern part.

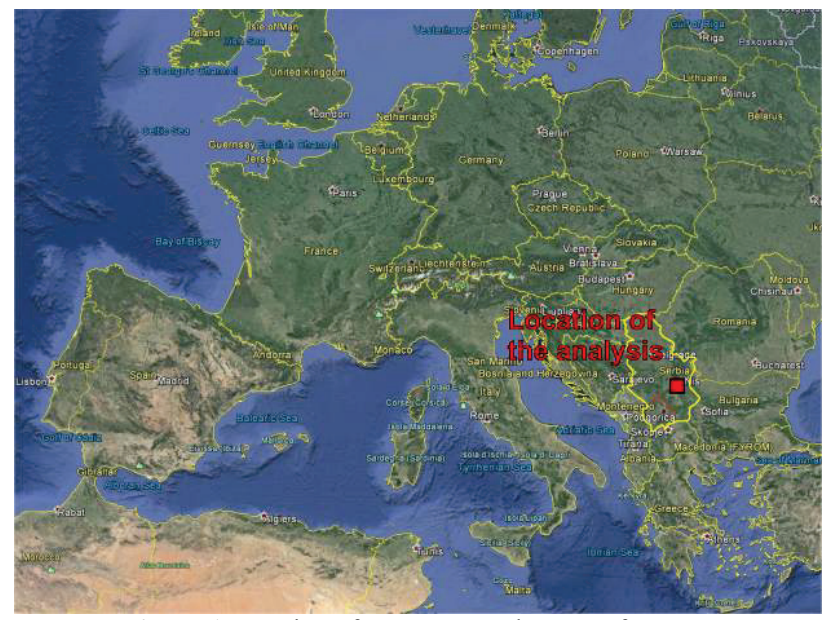

Figure 1 Location of Barutana on the map of Europe

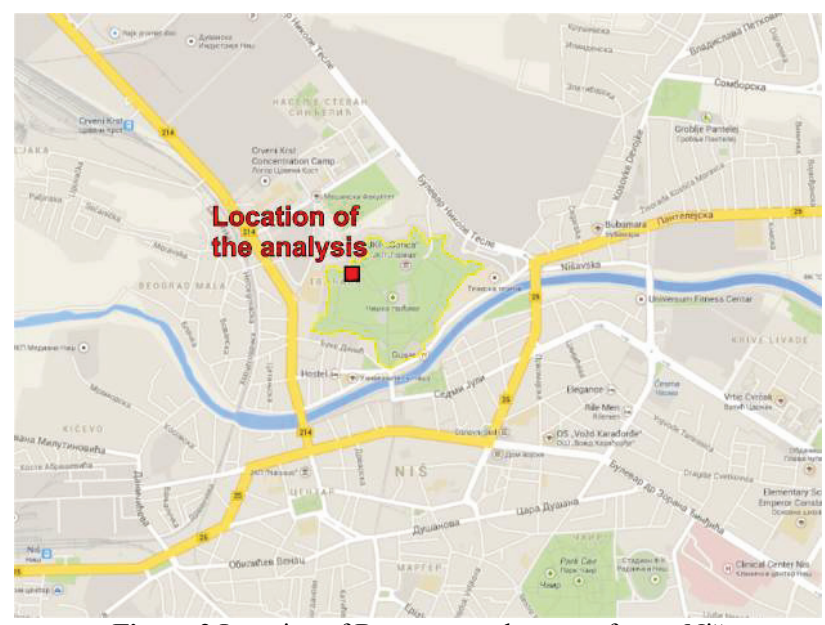

Figure 2 Location of Barutana on the map of town Niš

This part of study contains parallel analyses of semiautomatic and automatic photogrammetric methods on Barutana, which is located in the end west side of northern bastion of the fortress (Fig. 2). The inner rectangular space is surrounded by massive wall (over $1 \mathrm{~m}$ wide), serving for munitions and gun powder storing, while the outer narrow corridor had been protecting soldiers during enemy attacks. Through twelve narrow holes in the walls they had been shooting at the enemy and defending the building. These gun powder warehouses were built after 1723 year, when the fortress construction was finished. They are the rare examples of a kind preserved in Serbia from the period of the Ottoman rule.

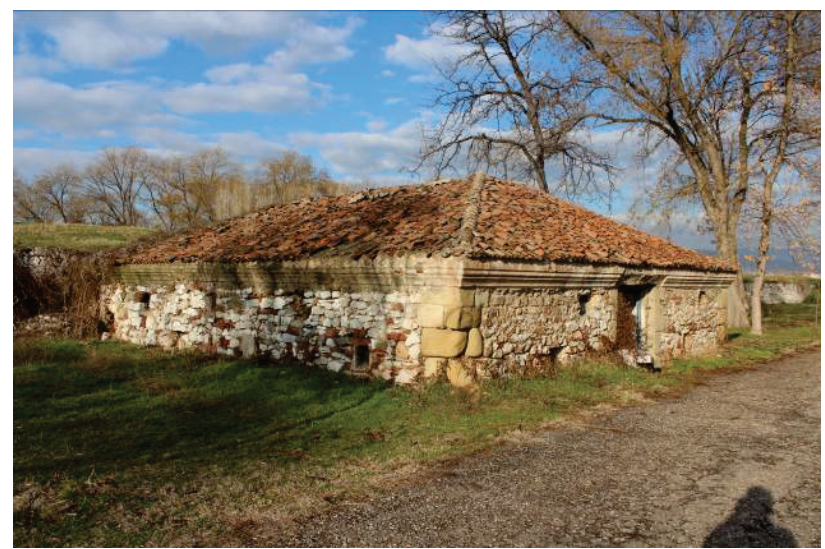

Figure 3 The south-west view - photo of Barutana

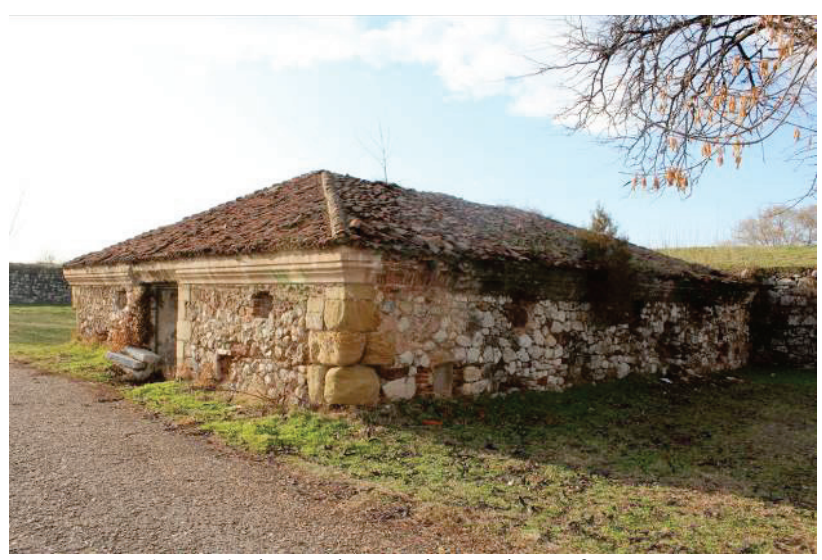

Figure 4 The south-east view - photo of Barutana

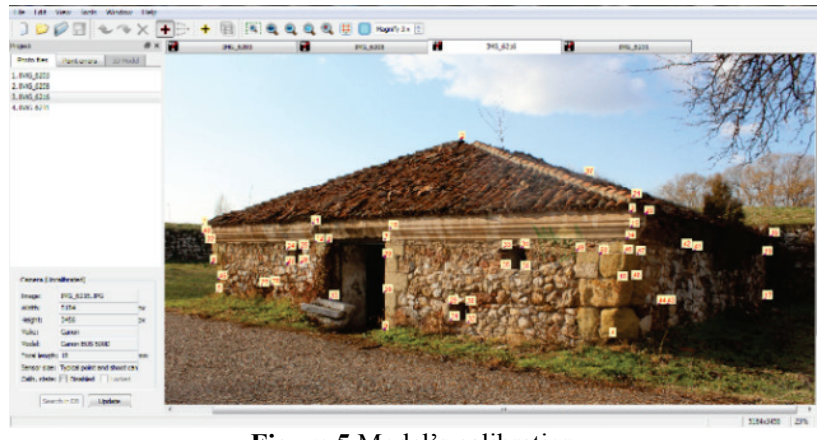

Figure 5 Model's calibration

\subsection{Creation of 3D model by using semi-automatic photogrammetric method}

3D model of Barutana processed photographic images taken by Canon EOS 600D camera, from various viewpoints (Fig. 3 and Fig. 4). Since the walls of Barutana are not perpendicular regarding: the age, architectural style, materials and preservation level, the adequate software package "Tgi3D Photo Scan" for calibration of photographic images is employed. Four images from different positions are chosen and imported 
in "Tgi3D Photo Scan". On each photographic image one locates and marks the characteristic calibration points on the building. This procedure had fifty repetitions (Fig. 5). Model scaling is done based on known distance do referent dimension (length) (Fig. 6) of the outer wall. "Tape Measure tool" in "Sketch Up" enabled scaling of the model to the $1: 1$ ratio.

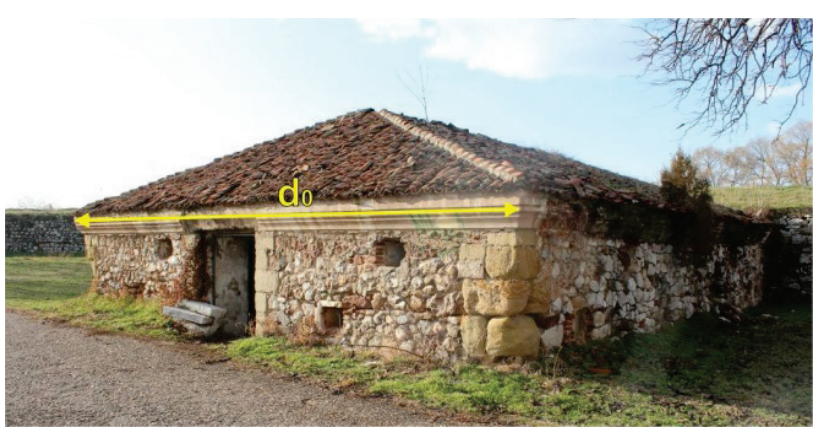

Figure 6 Referent distance

The final result of the entire process is a photorealistic 3D solid model of Barutana (Fig. 7). The level of detailness on Barutana's model, generated by semiautomatic photogrammetric method, directly depends on human factor (modeller's working time, his knowledge and experience). Hence, models created by using this method are simplified (example shown in Fig. 7). Model of Barutana presents just the main gabarit of the building, without detail on stone facades, with photorealistic textures. This kind of virtual model processing derives small size files, like in the case of Barutana's model (1.4 MB). Model like this is suitable for web sharing and presentation throughout "Google Earth" or "3D Warehouse" services, which are directly linked to "Sketch Up".

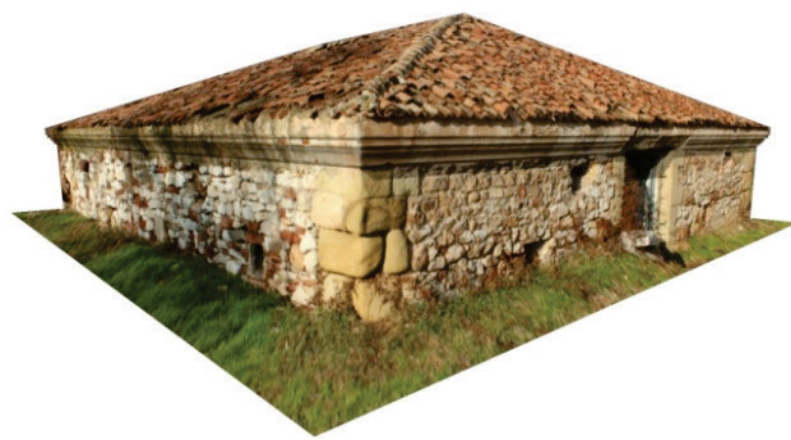

Figure 7 Final 3D model of Barutana

\subsection{Creation of 3D model by using automatic photogrammetric method}

Photographic recording of Barutana, necessary for this method, is also performed by the photo camera EOS 600D. Complete automatic photogrammetric method processing is done in share-ware software package "123D Catch".

Since the automatic photogrammetric method needs as many photographic images as possible, a series of images of Barutana (83 images) is taken along the given path around the building. Viewpoints were specified on 150 of angular distance (Fig. 8), positioned near loopholes in the walls in order to get detailed processing. Photographic images are entered in "123D Catch".

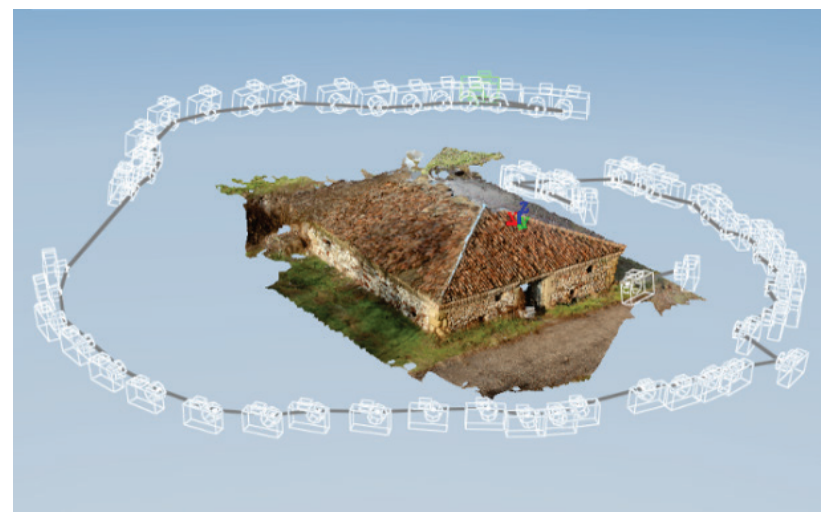

Figure 8 Defined path for serial of images

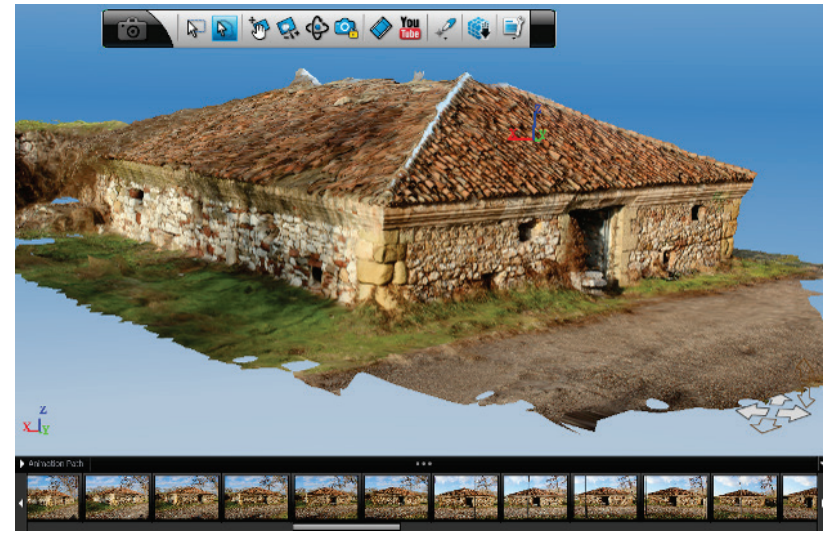

Figure 9 Drawing of model`s surfaces

When the software package "123D Catch" is concerned, the necessity is on line server data processing. It is, in fact, a user interface for data import and overview of the results, while the image calibration process and 3D model generating are separate operations elsewhere performed. After the process is done "123D Catch" takes over final 3D model of Barutana in an unknown proportion. Finally, the distance do (referent length) of two fixed points is needed for scaling. When defined, final 3D model of Barutana is in real size.

Human factor in here applied method is minimized, i.e. limited on image entering and model scaling. The entire process of photogrammetry and modelling is automated, and no other human interference is necessary.

The final result of the process is photo-realistic threedimensional "mesh surface" model of Barutana (Fig. 9), very precise and detailed. The exported file size of $3 \mathrm{D}$ model is $45 \mathrm{MB}$, suitable for web presentations, as well as for digital documentation of objects (buildings) or entire spatial entities.

\section{The results and discussion}

The comparative analyses of both methods, semiautomatic terrestrial photogrammetry and automatic terrestrial photogrammetry, on the model of old Ottoman Barutana in Niš, contained 15 defined control distances (Fig. 10)

For defined distances $\mathrm{d} 1 \div \mathrm{d} 15$, the measuring of real sizes is done, directly on Barutana and then compared to the same distances on two models generated by 
semiautomatic and automatic photogrammetric methods (Fig. 11).
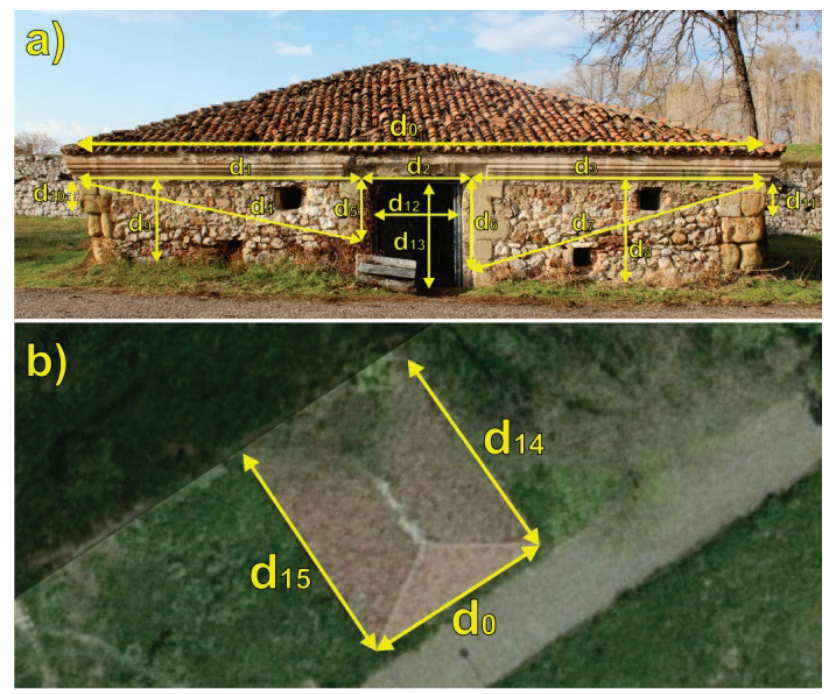

Figure 10 Control distances marking ( $\mathrm{a}-$ the facade, $\mathrm{b}$ - top view)
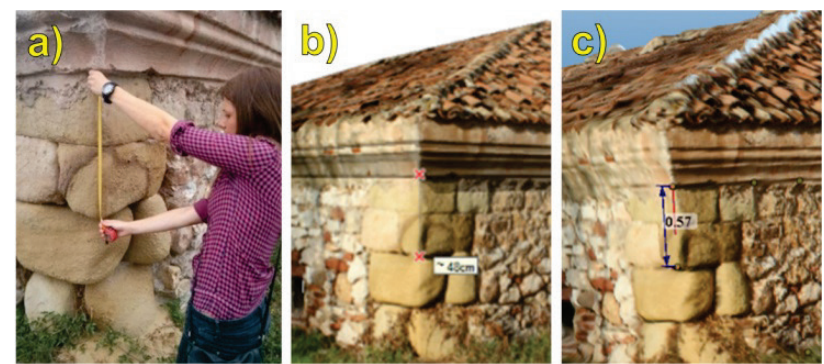

Figure 11 Measuring on: a) real object, b) 3D model (semiautomatic method), c) 3D model (automatic method)

All the results of measuring are shown in Tab. 1. The deviations of distances on real object and 3D models are calculated in percentages. The average values for deviations percentage is given on the bottom of the Tab. 1: for semiautomatic photogrammetric method $-3,87 \%$ and automatic photogrammetric method $-1,48 \%$.

The comparison of two presented methods (3D models) provided some information about their advantages or disadvantages and similarities or differences as well.

Table 1 Control measuring and distance deviation on the model

\begin{tabular}{|c|c|c|c|c|c|}
\hline \multirow[b]{2}{*}{ Distance mark } & \multicolumn{3}{|c|}{ Length $(\mathrm{cm})$} & \multicolumn{2}{|c|}{ Tolerance related to real length (\%) } \\
\hline & $\begin{array}{c}\text { Real } \\
\text { (measured) }\end{array}$ & $\begin{array}{c}\text { Semiautomatic } \\
\text { photogrammetry }\end{array}$ & $\begin{array}{c}\text { Automatic } \\
\text { photogrammetry }\end{array}$ & $\begin{array}{c}\text { Semiautomatic } \\
\text { photogrammetry }\end{array}$ & $\begin{array}{c}\text { Automatic } \\
\text { photogrammetry }\end{array}$ \\
\hline$d_{1}$ & 480 & 493 & 492 & 2,70 & 2,50 \\
\hline$d_{2}$ & 179 & 181 & 182 & 1,11 & 1,67 \\
\hline$d_{3}$ & 482 & 465 & 479 & 3,52 & 0,62 \\
\hline$d_{4}$ & 478 & 504 & 492 & 5,44 & 2,93 \\
\hline$d_{5}$ & 95 & 100 & 97 & 5,26 & 2,10 \\
\hline$d_{6}$ & 145 & 149 & 146 & 2,76 & 0,69 \\
\hline$d_{7}$ & 502 & 488 & 500 & 2,79 & 0,39 \\
\hline$d_{8}$ & 166 & 163 & 165 & 1,81 & 0,60 \\
\hline$d_{9}$ & 150 & 149 & 148 & 0,67 & 1,33 \\
\hline$d_{10}$ & 55 & 48 & 57 & 12,72 & 3,63 \\
\hline$d_{11}$ & 56 & 53 & 58 & 5,36 & 3,57 \\
\hline$d_{12}$ & 145 & 140 & 146 & 3,45 & 0,69 \\
\hline$d_{13}$ & 180 & 173 & 180 & 3,89 & 0,00 \\
\hline$d_{14}$ & 1435 & 1313 & 1402 & 8,50 & 2,29 \\
\hline$d_{15}$ & 968 & 988 & 974 & 2,06 & 0,62 \\
\hline \multicolumn{4}{|c|}{ Average tolerance value } & 3,87 & 1,48 \\
\hline
\end{tabular}

Both methods have in common the following characteristics and factors: convenience of virtualization of small objects (buildings), import data (photographic images and one known real distance), photo-realistic models and availability of free share-ware software packages.

The number of photographic images differs, i.e. semiautomatic photogrammetric method needs a significantly smaller number of images. This method involves expertness and experience in modelling, while the automatic photogrammetric method is the simplest automated. The difference between geometric characteristics of models is of importance too. The first method results in a solid model, while the other is a mesh surface.

Since the detailed quality of 3D model generated by semiautomatic method relies on human factor, automatic method gives a more detailed model. To achieve equal level of detail in both methods, one who carries out semiautomatic processing needs more working time. The other important aspect is file size, where the semiautomatic method has the primacy (smaller file size of the model).

\section{Conclusion}

3D virtual model generating, provided by contemporary computer technologies, has a wide palette of applications in various areas. Therefore, the methods of terrestrial photogrammetry are efficient, precise and qualitative modes for 3D modelling of existing objects, structures or spatial entities.

Two methods of terrestrial photogrammetry presented 3D modelling virtualization process through the case study of an old object named Barutana, located in the city of Niš. Three-dimensional models show certain deviations of dimensions: $3,87 \%$ for semiautomatic, and $1,48 \%$ for automatic method. The results are upgraded from earlier research (Pejic and Krasic, Nexus 2013), where deviations were $4,84 \%$ for semiautomatic, and $1,77 \%$ for 
automatic method. Since all the factors during model processing are the same as previous, except the type of a building, the conclusion is that precision depends on building preservation and its orthogonality. The significant difference in geometric precision of 3D models obtained by semiautomatic and automatic photogrammetric methods is a direct result of human influence. If the human interference is smaller (automatic method), the precision is higher. Hence, automatic photogrammetric method enables accurate 3D models, suitable for digital documentation, precise analyses and photo-realistic high quality model presentations. Disadvantages of this method are large file sizes. Web presentations, analyses of urban entities (where the models are in the background), or visualizations prefer smaller files, where the semiautomatic photogrammetric method is of use. It is reasonable to assume that further development of technologies will bring the primacy to the automation in virtual 3D model generating.

Future research will concern the possibilities of 3D model presentations by virtual and extended reality. We expect the improvement of methodologies in $3 \mathrm{D}$ model generating of real objects.

\section{Acknowledgements}

The authors gratefully acknowledge the Department of Visual Communications, Faculty of Civil Engineering and Architecture - University of Niš, Serbia for support during research.

\section{References}

[1] Styliadis, D. A. Digital documentation of historical buildings with 3-D modeling functionality. // Automation in Construction. 16(2007), pp. 498-510. DOI 10.1016/j.autcon.2006.09.003

[2] Stojakovic, V.; Tepavcevic, B. Image-based modeling approach in creating 3D morphogenetic reconstruction of Liberty Square in Novi Sad. // Journal of Cultural Heritage. 12(2011), pp. 105-110. DOI: 10.1016/j.culher.2010.06.001

[3] Pejic, P.; Krasic, S.; Nikolic, O. Creation of architectonic 3D models by contemporary photogrammetry methods. // Proceedings of the Int. conference MoNGeometrija 2012 / Faculty of Technical Sciences, Novi Sad, 2012, pp. 289297.

[4] Del Pizzo, S.; Troisi, S. Automatic orientation of image sequences in cultural heritage. //Proceedings of the ISPRS Trento / Trento, 2011, pp. 293-300.

[5] De Luca, L. Methods, Formalisms and tools for the semantic-based surveying and representation of architectural heritage. // Applied Geomatics. 12, 2(2011), pp. 115-139. DOI: 10.1007/s12518-011-0076-7

[7] Xiao, J.; Gerke, M.; Vosselman, G. Building extraction from oblique airborne imagery based on robust façade detection. // ISPRS Journal of Photogrammetry and Remote Sensing. 68(2012), pp. 56-68. DOI: 10.1016/j.isprsjprs.2011.12.006

[8] Chane, S. C.; Mansouri, A.; Marzani, S.; F., Boochs, F. Integration of $3 \mathrm{D}$ and multispectral data for cultural heritage applications: Survey and perspectives. // Image and Vision Computing. 31(2013), pp. 91-102. DOI 10.1016/j.imavis.2012.10.006

[9] Wirtz, S.; Decker, P.; Paulus, D. Semiautomatic generation of semantic building models from image series. // Proceedings of the SPIE 8290, Three-Dimensional Image
Processing (3DIP) and Applications II / Burlingame, 2012. DOI: $10.1117 / 12.908489$

[10] Altan, O.; Toz, G.; Kulur, S.; Seker, D.; Volz, S.; Fritsch, D.; Sester, M. Photogrammetry and geographic information systems for quick assessment, documentation and analysis of earthquakes. // ISPRS Journal of Photogrammetry \& Remote Sensing. 55(2001), pp. 359-372. DOI: 10.1016/S0924-2716(01)00025-9

[11] Arias, P.; Armesto, J.; Di-Capua, D.; Gonzalez, D. R.; Lorenzo, H.; Perez, G. V. Digital photogrammetry, GPR and computational analysis of structural damages in a mediaeval bridge. // Engineering Failure Analysis. 14(2007), pp. 1444-1457. DOI: 10.1016/j.engfailanal.2007.02.001

[12] Armesto, J.; Lubowiecka, I.; Ordó-ez, C.; Rial, I. F. FEM modeling of structures based on close range digital photogrammetry. // Automation in Construction. 18(2009), pp. 559-569. DOl: 10.1016/j.autcon.2008.11.006

[13] Elaksher, F. A. 3D object reconstruction from multiple views using neural networks. // Applied Geomatics. 5(2013), pp. 193-201. DOI: 10.1007/s12518-013-0110-z

[14] Hong, T. L.; Laefer, F. D.; Hinks, T.; Carr, H. Combining an Angle Criterion with Voxelization and the Flying Voxel Method in Reconstructing Building Models from LiDAR Data. // Computer-Aided Civil and Infrastructure Engineering. 28(2013), pp. 112-129. DOI: 10.1111/j.14678667.2012.00761.x

[15] Walsh, B. S.; Borello, J. D.; Guldur, B.; Hajjar, F. J. Data Processing of Point Clouds for Object Detection for Structural Engineering Applications. // Computer-Aided Civil and Infrastructure Engineering. 28(2013), pp. 495508. DOI: $10.1111 /$ mice. 12016

[16] Tack, F.; Buyuksalih, G.; Goossens, R. 3D building reconstruction based on given ground plan information and surface models extracted from space borne imagery. // ISPRS Journal of Photogrammetry and Remote Sensing. 67(2012), pp. 52-64. DOI: 10.1016/j.isprsjprs.2011.10.003

[17] Lafarge, F.; Mallet, C. Creating Large-Scale City Models from 3D-Point Clouds: A Robust Approach with Hybrid Representation. // International Journal of Computer Vision, 99(2012), pp. 69-85. DOI: 10.1007/s11263-012-0517-8

[18] Heo, J.; Jeong, S.; Park, K. H.; Jung, J.; Han, S.; Hong, S.; Sohn, G. H. Productive high-complexity 3D city modeling with point clouds collected from terrestrial LiDAR. // Computers, Environment and Urban Systems. 41(2013), pp. 26-38. DOI: 10.1016/j.compenvurbsys.2013.04.002

[19] Musialski, P.; Wonka, P.; Aliaga, D. G.; Wimmer, M.; van Gool, L.; Purgathofer, W. A Survey of Urban Reconstruction. // Computer graphics forum. 6(2013). pp. 146-177. DOI: $10.1111 / \mathrm{cgf} .12077$

[20] Rawashdeh, B. S. Assessment of extraction drainage pattern from topographic maps based on photogrammetry. // Arabian Journal of Geosciences. 6, 12(2012), pp. 48734880. DOI: 10.1007/s12517-012-0718-z

[21] Turowski, M. J.; Badoux, A.; Rickenmann, D.; Kohoutek, K. T.; Pauli, M.; Kirchner, W. J. Range imaging: a new method for high-resolution topographic measurements in small- and medium-scale field sites. // Earth Surface Processes and Landforms. 38(2013), pp. 810-825. DOl: 10.1002/esp.3322

[22] Curtaz, M.; Ferrero, A. M.; Roncella, R.; Segalini, A.; Umili, G. Terrestrial Photogrammetry and Numerical Modelling for the Stability Analysis of Rock Slopes in High Mountain Areas: Aiguilles Marbrees case. // Rock Mechanics and Rock Engineering. 47, 2(2013), pp. 605620. DOI: $10.1007 / \mathrm{s} 00603-013-0446-\mathrm{z}$

[23] Fonstad, A. M.; Dietrich, T. J.; Courville, C. B.; Jensen, L. J.; Carbonneau, E. P. Topographic structure from motion: a new development in photogrammetric measurement. // 
Earth Surface Processes and Landforms. 38(2013), pp. 421430. DOI: $10.1002 /$ esp.3366

[24] Lato, M.; Kemeny, J.; Harrap, R. M.; Bevan, G. Rock bench: Establishing a common repository and standards for assessing rockmass characteristics using LiDAR and photogrammetry. // Computers \& Geosciences. 50(2013), pp. 106-114. DOI: 10.1016/j.cageo.2012.06.014

[25] Menna, F.; Nocerino, E. Hybrid survey method for 3D digital recording and documentation of maritime heritage. // Applied Geomatics. 6, 2(2014), pp 81-93. DOl: 10.1007/s12518-011-0074-9

[26] Berretti, S.; Bimbo, A.; Pala, P. Automatic facial expression recognition in real-time from dynamic sequences of 3D face scans. // The Visual Computer. 29, 12(2013), pp. 1333-1350. DOI: 10.1007/s00371-013-0869-2

[27] Lerma, L. J.; Navarro, S.; Cabrelles, M.; Villaverde, V. Terrestrial laser scanning and close range photogrammetry for 3D archaeological documentation: the Upper Palaeolithic Cave of Parpallo as a case study. // Journal of Archaeological Science. 37(2010), pp. 499-507. DOI: 10.1016/j.jas.2009.10.011

[28] Haydar, M.; Roussel, D.; Madjid, M.; Otmane, S.; Mallem, M. Virtual and augmented reality for cultural computing and heritage: a case study of virtual exploration of underwater archaeological sites. // Virtual Reality. 15(2011), pp. 311-327. DOI: 10.1007/s10055-010-0176-4

[29] Kersten, T. P.; Stallmann, D. Automatic texture mapping of architectural and archaeological 3D models. // Proceedings of the XXII ISPRS Congress / Melbourne, 2012, pp. 273278. DOI: 10.5194/isprsarchives-xxxix-b5-273-2012

[30] Kochi, N.; Ito, T.; Kitamura, K.; Kaneko, S. Development of 3D Image Measurement System and Stereo-Matching Method, and Its Archaeological Measurement. // Electronics and Communications in Japan. 6(2013), pp. 391-400. DOI: 10.1002/ecj.11459

[31] Rawashdeh, B. S. Archaeological documentation based on geomatic techniques for Roman amphitheater in Amman City. //Applied Geomatics. 5(2013), pp. 241-246. DOl: 10.1007/s12518-013-0112-x

[32] Ruzouq, I. A.; Abueladas, A. A. Geomatics techniques and ground penetration radar for archaeological documentation of Al-Salt castle in Jordan. // Applied Geomatics. 5, 4(2013), pp. 255-269. DOI: 10.1007/s12518-013-0116-6

[33] Gonzalez, A. D.; Gomez, L. J. Forensic Terrestrial Photogrammetry from a Single Image. // Journal of Forensic Sciences. 6(2009), pp. 1376-1387. DOI: 10.1111/j.1556-4029.2009.01170.x

[34] Pejic, P.; Krasic, S.; Lukic, P.; Romic, N. Comparative analysis of methods for creating tree-dimensional models of urban complex. // Proceedings of the Int. conference contemporary theory and practice in building development / Banja Luka 9, 2013, pp. 393-404.

[35] Pejić, P.; Krasić, S.; Bjelić, I. Comparative Study on Photogrammetric Methods for 3D Modeling of Building Heritage. // Scientific Bulletin of the Universitatii Politehnica din Timisoara, Romania, 58(2013), pp. 87-91.

[36] Ergun, B.; Sahin, C.; Baz, I.; Ustuntas, T. A case study on the historical peninsula of Istanbul based on threedimensional modeling by using photogrammetry and terrestrial laser scanning. // Environ Monit Assess. 165(2010), pp. 595-601. DOI: 10.1007/s10661-009-0971-0

[37] Oliveira, A.; Oliveira, F. J.; Pereira, M. J.; Araujo, R. B.; Boavida, J. 3D modelling of laser scanned and photogrammetric data for digital documentation: the Mosteiro da Batalha case study. // Journal of Real-Time Image Processing. 9, 4(2012), pp. 1-16.

[38] Murphy, M.; McGovern, E.; Pavia, S. Historic Building Information Modelling - Adding intelligence to laser and image based surveys of European classical architecture. //
ISPRS Journal of Photogrammetry and Remote Sensing. 76(2013), pp. 89-102. DOl: 10.1016/j.isprsjprs.2012.11.006

[39] Santos, R. D.; Poz, P. A.; Khoshelham, K. Indirect georeferencing of terrestrial laser scanning data using control lines. // The Photogrammetric Record. 28(2013), pp. 276-292. DOI: 10.1111/phor.12027

[40] Yang, B.; Fang, L.; Li, J. Semi-automated extraction and delineation of 3D roads of street scene from mobile laser scanning point clouds. // ISPRS Journal of Photogrammetry and Remote Sensing. 79(2013), pp. 80-93. DOI: 10.1016/j.isprsjprs.2013.01.016

[41] Yilmaz, H. M.; Yakar, M.; Gulec, S. A.; Dulgerler, O. N. Importance of digital close-range photogrammetry in documentation of cultural heritage. // Journal of Cultural Heritage. 8(2007), pp. 428-433. DOI: 10.1016/j.culher.2007.07.004

[42] Barazzetti, L.; Scaioni, M.; Remondino, F. Orientation and 3D modeling from markerless terrestrial images: combining accuracy with automation. // The Photogrammetric Record. 25(2010), pp. 356-381. DOI: 10.1111/j.14779730.2010.00599.x

[43] Irschara, A.; Kaufmann, V.; Klopschitz, M.; Bischof, H.; Leberl, F. Towards Fully Automatic Photogrammetric Reconstruction Using Digital Images Taken From UAVs. // Proceedings of International Society for Photogrammetry and Remote Sensing Symposium, 100 Years ISPRS Advancing Remote Sensing Science / Vienna, 2010, pp. $65-$ 71.

[44] Remondino, F.; Rizzi, A. Reality-based 3D documentation of natural and cultural heritage sites-techniques, problems, and examples. //Applied Geomatics. 2(2010), pp. 85-100. DOI: $10.1007 / \mathrm{s} 12518-010-0025-x$

[45] Vallet, B.; Deseilligny, P.; M., Boldo, D.; Brédif, M. Building footprint database improvement for 3D reconstruction: A split and merge approach and its evaluation. // ISPRS Journal of Photogrammetry and Remote Sensing. 66(2011), pp. 732-742. DOI: 10.1016/j.isprsjprs.2011.06.005

[46] Wefelscheid, C.; Hansch, R.; Hellwich, O. Threedimensional building reconstruction using images obtained by unmanned aerial vehicles. // Proceedings of the ISPRS Zurich 2011 Workshop / Zurich, 2011, pp. 183-188.

[47] Ozgun, O. A. Automated detection of buildings from single VHR multispectral image using shadow information and graph cuts. // ISPRS Journal of Photogrammetry and Remote Sensing. 86(2013), pp. 21-40. DOI: 10.1016/j.isprsjprs.2013.09.004

[48] Pejic, P.; Krasic, S. Modern methods of three dimensional presentations of the building heritage. // Proceedings of the IV international symposium for students of doctoral studies in the fields of civil engineering, architecture and environmental protection / Nis, 2012, pp. 111-119.

[49] Stojakovic, V. Terrestrial photogrammetry and application to modeling architectural objects. // Facta universitatis, Series: Architecture and Civil Engineering. 1, 6(2008), pp. 113-125. DOI: 10.2298/fuace0801113s 


\section{Authors' addresses}

Petar Pejić, M.Sc., PhD student (corresponding author) Faculty of Technical Sciences, University of Novi Sad, Trg Dositeja Obradovića 6, 21000 Novi Sad, Serbia petarpejic@i.ua

Sonja Krasić, PhD, Associate Professor

Faculty of Civil Engineering and Architecture, University of Niš, Aleksandra Medvedeva 14, 18000 Niš, Serbia

krasic.sonja@gmail.com

Hristina Krstić, M.Sc., PhD student

Faculty of Civil Engineering and Architecture, University of Niš,

Aleksandra Medvedeva 14, 18000 Niš, Serbia

hristinaa@hotmail.com

Magdalena Dragović, PhD, Assistant Professor

Faculty of Civil Engineering, University of Belgrade, Serbia

Bulevar kralja Aleksandra 73, 11000 Beograd, Serbia

dim@grf.bg.ac.rs

\section{Yağız, Akbiyik}

Mühendislik Fakültesi, Marmara Üniversitesi, İstanbul, Türkiye Goztepe Campus Kadıkoy 34722 - Istanbul, Türkiye

yagizakbiyik@gmail.com 